\title{
Effects of Central Decisions on Local Livelihoods in Indonesia: Potential Synergies between the Programs of Transmigration and Industrial Forest Conversion
}

\author{
C. M. O'Connor \\ University of Michigan
}

\begin{abstract}
In addition to well-documented negative effects (e.g., environmental degradation and ethnic conflict) Indonesia's central government programs of transmigration and industrial forest management subvert indigenous rights (even if unintentionally) through appropriation of forested land and migrant subsidies. Although central control can be an effective strategy for resource management, Indonesia's programs have undercut their own objectives and may interact synergistically to increase population pressure, reduce available land, and intensify land use conflicts on the outer islands. Empirical data are needed to evaluate the interactions between transmigration and forest conversion and to design appropriate management strategies that incorporate local as well as central controls.
\end{abstract}

KEY WORDS: transmigration; logging concessions; Dayak; ethnic conflict; resource degradation.

\section{INTRODUCTION}

Environmental management and community development in the tropics involve multiple stakeholders and a complex suite of interdisciplinary issues surrounding contested land use claims. Such issues include increasing population pressures; industrialization of logging concessions, plantations, agriculture and mining; unequal access to forest resources and to policies affecting those resources; changes in subsistence economies;

Please address correspondence to C. M. O'Connor, Urban Ecology Institute, 355 Higgins Hall, 140 Commonwealth Avenue, Chestnut Hill, MA 02467. 
environmental degradation; and social unrest. These large-scale difficulties arise as people's lives and livelihoods are changed, in this case inadvertently. In Indonesia, uneven population distribution, great differences in power and influence among socio-economic groups, and history of corrupt authoritarian governance (1967-1999), have led to severe problems of resource management, access, and control.

Increasingly, international attention has focused on Indonesia's environmental crises, because they have major implications for regional stability and ethnic conflict. Two of Indonesia's major government programs, transmigration and industrial forest conversion, have led to well-documented, unintended consequences of environmental degradation and ethnic unrest. These two programs may interact synergistically to intensify land use conflicts and disenfranchise local forest-dependent communities. While central control is often viewed as the best way to manage natural resources and multi-state issues, there must be opportunities for public participation and checks and balances to ensure sound management.

\section{CENTRAL GOVERNMENTAL CONTROL IN INDONESIA}

Indonesia is a nation of 17,000 islands, with hundreds of ethnic groups and languages, rich biodiversity, and abundant natural resources, including timber, oil, natural gas, and minerals. The diverse biogeography of these islands has determined much of the country's political, social, and economic development. United under Dutch colonial rule, the islands have remained together as one country though a system of strong central government control that includes military might, ideological propaganda, population management, and central control of natural resources. Since independence in 1949, Indonesia's presidents have enjoyed near dictatorship, and elite decision-makers from Java have determined the course of local affairs throughout the archipelago.

Although central control has, for the most part, successfully maintained Indonesia's national identity, it has also been linked to high levels of regional inequality (Shankar \& Shah, 2003). The central government programs of transmigration and industrial forest conversion stand out as policies that have led to corruption, mismanagement of resources, and ethnic strife. For example, transmigration, state-sponsored migration from the densely-populated inner islands (Java, Bali, and Madura) to the sparsely-populated outer islands (Sumatra, Kalimantan, and West Papua), has led to widespread ethnic conflict and environmental degradation. Indonesia's central management of natural resources has had grave impacts on the ecology of the 
outer islands, as well as the livelihoods of rural, forest-dependent communities. In this review, I explore the consequences of and interactions between these two major central government policies, transmigration and industrial forest conversion.

\section{TRANSMIGRATION}

In response to increasing population pressure, developing countries around the world are encouraging population redistribution, often through government-sponsored resettlement programs such as the well-publicized programs in Brazil and Indonesia (Desbarats, 1990; Ilchman, Lasswell, Montgomery, \& Wiener, 1975). In general, Indonesia's programs have been unsuccessful in achieving governmental goals of population reduction (Oey, 1981). Further, the increasing population pressures and cultural displacement associated with the transmigration program have led to environmental degradation (Fearnside, 1997; Lumbranraja et al., 1998) and ethnic conflicts throughout transmigrant areas.

\section{History and Goals}

The population of Indonesia, currently around 235 million (CIA, 2003), is unevenly distributed. The "outer" island provinces, such as West Kalimantan and West Papua, have extremely low population densities (12 and 6 persons per $\mathrm{km}^{2}$, respectively; BPS, 2004). In contrast, the central islands of Java and Bali, with their rich volcanic soils, can support more than 1000 people per $\mathrm{km}^{2}$ (BPS, 2004; Hugo, 1980). Responding to this extreme variation, Indonesia's population policy has focused on redistribution.

In 1905, the Dutch began a "colonization" program to resettle people from the inner islands to the outer islands, primarily to provide cheap plantation labor (Abdoellah, 1987; Dawson, 1994). After independence in 1949, the Indonesian government continued the program, renamed "transmigration," to alleviate population pressure and promote national unity (Elmhirst, 1999; Hull \& Hatmadji, 1990). Government funding is directed almost exclusively at very poor, rural inhabitants of the inner islands (Zakaria, 1996). Families are subsidized for up to five years, after which time they are considered independent and are "turned over" to the local governments to be integrated into local villages (Fasbender \& Erbe, 1990).

People are motivated to move for diverse but predictable reasons: economic hardship and unequal access to resources; ecological deterioration; improved communication and transportation; and desire for better 
opportunities in education and social services. Generally, migrants are affected by a "sense of relative deprivation in some important values and the belief that this cannot be overcome at home but might be overcome somewhere else" (Abdoellah, 1987, 182). On the island of Java, land is a precious commodity, and land tenure is uncertain, so the chance to secure a plot through the transmigration program is appealing (Fasbender \& Erbe, 1990).

In South and Central Kalimantan, most migrants were from the poorest households in Java, and had less education than the national average (Karyono, Abdoellah, \& Siswandono, 1980). Land ownership and willingness to migrate were negatively related; people who lived in villages with a shortage of land, and unequal access to land, were most likely to migrate. Most transmigrants are farm laborers, tenant farmers, or farmers with plots too small to make a living (Dawson, 1994).

Migrants are usually unfamiliar with the types of soils and appropriate farming techniques in their new region. The land in transmigration settlements is usually poor soil, ill-suited to the wet rice cultivation that transmigrants are used to and that the government promotes. Migrants are usually able to obtain reasonable rice yields at first, but after several years the soils become depleted and the yields fall. In a study in Sumatra, $65 \%$ of the transmigrant population was living in poverty (Holden, Hvoslef, \& Simanjuntak, 1995).

\section{Effects and Consequences}

I compiled data from relevant published studies, and from the 1980 national census. There are no regular publications of birth and death registration statistics in Indonesia, as in most developing countries, so demographers rely on decennial population censuses and intercensal surveys, both of which estimate fertility only indirectly (Hull \& Dasvarma, 1987; Suharto \& Cho, 1978). Census data are grouped into subprovincial areas, and it is difficult to get data for smaller regions such as regencies, municipalities, or subdistricts. "Source areas" were considered to be any parts of Java, Madura, and Bali; "destination areas" were well-known transmigration settlements, including Lampung in southern Sumatra and West Kalimantan in Borneo.

Population redistribution: In her study of fertility in transmigrant communities, Oey (1981) found that in relocating families to relieve population pressure on Java, the government increased pressure on the outer islands. While the overall density of Sumatra is about 90 people per $\mathrm{km}^{2}$, the density of Lampung, a large transmigrant destination, is 200 people per $\mathrm{km}^{2}$. Oey 
found that fertility was higher in the transmigrant community of Lampung than in either the home communities on Java or the non-migrant communities of Lampung. Similarly, Clauss et al. (1987) report that from 1971 to 1980, the growth rate in transmigrant communities in Sumatra and Kalimantan was almost $20 \%$ higher than the natural growth rate in these regions. These increases in fertility suggest that the transmigration program is subverting its own goals as well as the goals of the family planning program (Ilchman et al., 1975).

Traditional demographic theories do not fit the transmigration data: there are no links between observed fertility differences and any demographic and social indicators, such as patterns of marriage, child mortality, family planning, or education (Oey, 1981). Demographic transition theories have often fallen short in explaining fertility changes (Cohen, 1995; Robey, Rutstein, \& Morris, 1993), and it is important to explore additional approaches. One such approach, based on evolutionary principals, predicts that fertility will increase with increasing resources, or when people perceive that their income and resources are favorable compared to others (Abernathy \& Penaloza, 2002; Clarke \& Low, 2001; Low, 1993, 2001; Low, Clarke, \& Lockridge, 1992). Fertility should decline when parents can improve the net success of their offspring by investing more in each child and having fewer children (Low et al., 1992, Low, 2001). A sense of uncertainty will also affect reproductive decisions (Geronimus, 1996; Rank, 1989), and there is both theoretical and empirical support for the idea that families in Indonesia will have more children to mitigate risks associated with a poor, rural farming existence (Hull, 1976; Jones, 1976). Women's perceptions and decision-making power, in particular, are important determinants of fertility. Some researchers have proposed that women's relative power within the family increases with migration, as the couple distances itself from their families, and particularly, from the husband's family (Williams, 1986).

Thus, one would predict that fertility is higher among migrants who moved with expectations of a better life, and who benefit from more resources in the form of government subsidies. This is consistent with observed patterns (Figure 1; Clauss, Evers, \& Gerke, 1987; Oey, 1981), which indicate that age-specific fertility is higher in settlement areas than in source areas. If, after several years, the quality of life remains higher in the new environs, migrant fertility will remain higher than fertility in source areas. If, on the other hand, quality of life is poorer than expected, migrant fertility should drop below local fertility levels. In Lampung during 1976-79, there was an initial rise in age-specific fertility followed by a decline (Figure 2). More detailed longitudinal research is needed to see if these patterns are 


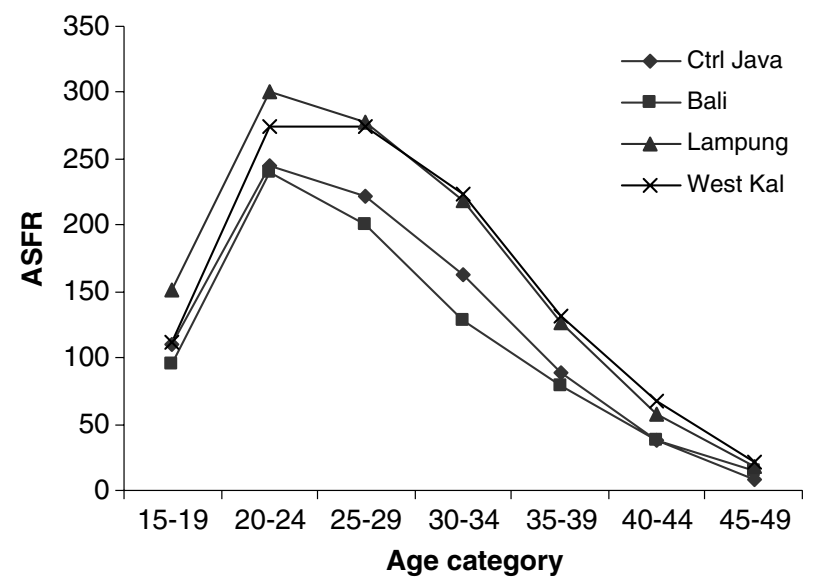

Figure 1. Age-specific fertility rate (ASFR) between 1976 and 1979, the early years of the transmigration program. Data are from the 1980 Census. Central Java (Ctrl Java) and Bali are "source areas" in the densely populated inner islands. Lampung, Sumatra, and West Kalimantan (West Kal) are "destination areas" where many transmigrants settled.

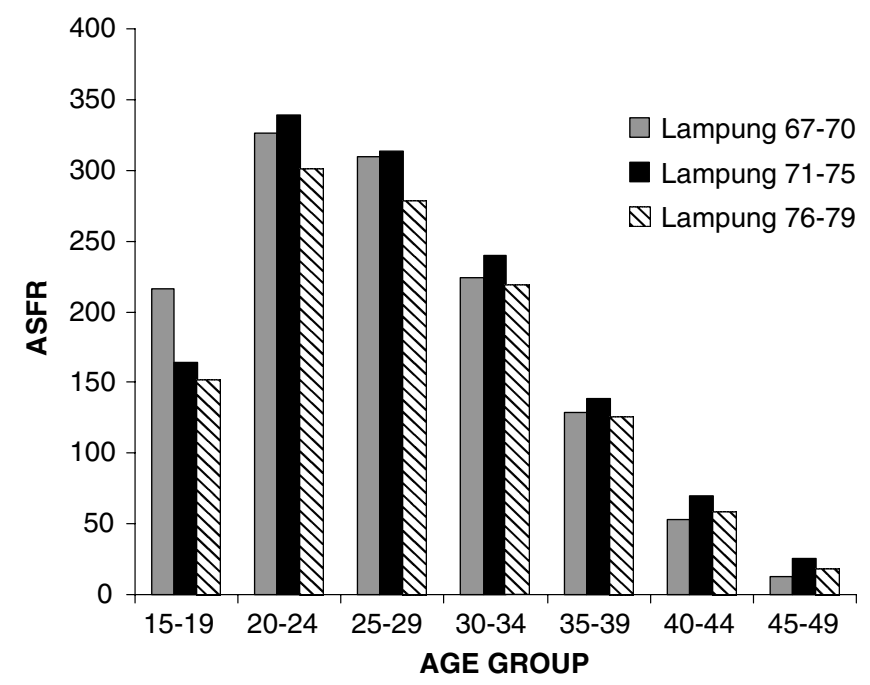

Figure 2. Age-specific fertility rate (ASFR) between 1967 and 1979, the early years of the transmigration program, in Lampung, a "destination area" in southern Sumatra. Data are from the 1980 Census. 
significant and if they correlate with successful arrival followed by hardship several years later.

National unity. Despite the government goal of integration and unification, transmigrant communities on the outer islands usually remain segregated from native residents. They maintain their own cultural and agricultural practices, and the original inhabitants often resent the government subsidies that migrants receive (Oey, 1981). Most migrants bring into the new communities the Javanese system of governance, perpetuating the idea that transmigration is a form of cultural imperialism, another mechanism for the "Javanization" of Indonesia (Elmhirst, 2000). Migrants compete for land and resources with local residents; and migrants often seek work in industrial plantations, which is viewed by local residents as stealing both land and jobs. Cultural clashes and resource shortages have led to severe ethnic conflict in transmigration areas, such as the violence between the Dayak (local residents) and Madurese (migrants) in Kalimantan. National unity is strained, rather than promoted, by the transmigration program.

\section{INDUSTRIAL FOREST CONVERSION}

\section{Concessions, Plantations, and Forest-dependent Communities}

Forest resources are central to the economy of Indonesia, as well as to the livelihoods of rural forest-dependent people. In 1960, the Indonesian government proclaimed that all natural resources were subject to state control and management (Basic Agrarian Law; State Gazette 160, No. 104, Law No. 5). In the late 1960s, Suharto (Indonesian president, 1966-1998) partitioned the lands of the outer islands-Sumatra, Kalimantan (Indonesian Borneo), and Irian Jaya - and granted extraction rights to industrial logging companies across almost $80 \%$ of the forested areas (Broad \& Cavanagh, 1994; Curran et al., 1999). Logging companies were granted 35-year leases, after which time they could renew the lease or abandon the land. Over time, as leases are abandoned, deforested areas have been turned into industrial plantations, primarily oil palm monocultures. Almost $25 \%$ of the land in West Kalimantan, for example, was allotted to industrial plantations in 2002 (Curran et al., 2004).

In Kalimantan, land use issues among multiple-stakeholders, including concessions, plantations, protected areas, subsistence communities, and transmigrants, are particularly contentious. The many indigenous, forestdependent communities in interior Borneo are collectively referred to as the Dayak peoples (MacKinnon, Hatta, Halim, \& Mangahik, 1997; Wadley, 
Pierce Colfer, \& Hood, 1997). Living in sedentary villages, Dayaks practice composite agrarian strategies, including shifting subsistence agriculture, gathering and cultivating forest products, trade, and wage labor.

When the government apportioned its natural resources in the 1960s, the majority of indigenous communities on the outer islands were subsumed within logging concessions. Traditional adat rights—resource rights that are determined and controlled by communities without formal title-were recognized only insofar as they did not conflict with national laws. Under the Basic Agrarian Law, all land must be registered, and land without title is assumed to belong to the state (MacAndrews, 1986). Within the concessions, local communities nominally retain rights to land they have already cleared and to important honey and fruit trees. However, these rights are rarely enforced (Barber, 1998), and communities are left to negotiate more concrete protections for their lands on their own. Local residents are not allowed to cut timber in any logging blocks; this right is reserved solely for the concessionaire.

The concession system was designed to facilitate the efficient extraction, marketing, and sale of timber, and it has achieved this goal. Today the forestry sector is one of the most important to Indonesia's economy; over the past 20 years, Indonesia's timber exports exceeded those of Africa and Latin America combined (Curran et al., 2004). A more covert but equally farreaching goal of the system was to reward wealthy and politically influential allies with lucrative business deals. By 1994, after years of consolidations and mergers, 25 individuals controlled rights to over 60 million ha of forests (Gunawan, Thamrin, \& Suhendar, 1999).

\section{Effects and Consequences}

Inconsistencies between official land use policies and actual outcomes in forested areas have existed for decades. It is common, for example, for large areas of the outer islands to be officially designated as both production forest and protected forest. These inconsistencies may represent conflicting priorities, lack of information, or poor communication, but in practice they have allowed the government to claim that it is conscientiously caring for its forests and people, while elite interests profit at the expense of local communities and the environment. Rife corruption, perverse incentives, and lack of accountability have led to a system of forest exploitation that is unsustainable and inequitable.

Illegal logging. Currently, illegal logging accounts for $55-75 \%$ of industrial wood production in Indonesia (CIFOR, 2002), with profits going primarily to private individuals and companies rather than the state. The 
efficient concession system, high potential profits, and total lack of legal enforcement have led to widespread deforestation on the outer islands. Protected lowland areas, rich in valuable timber species such as the Dipterocarpaceae, have been particularly devastated (Curran et al., 2004).

The central government continues to shape the debate by publicizing local swidden agriculturalists as the primary agents of deforestation. The government, which prefers uses of land that provide greater monetary return to those with political power (Gunawan et al., 1999), often promotes development schemes based on erroneous notions of the ecological impact of shifting agriculture (Cairns \& Garrity, 1999; de Jong, 1997; Dove, 1986; Fox, 2000).

Subsistence strategies. The environmental consequences of industrial logging and plantations are generally acknowledged, although typically underestimated. Less commonly assessed are the effects of deforestation on local communities. Concessions reduce the amount of land available to local communities-communities that have lived in these watersheds for generations-and at the same time increase population pressure, deplete resources, and degrade the landscape.

Longitudinal surveys indicate that Dayak families living within a logging concession in Central Kalimantan have experienced declines in rice harvests. Rice self-sufficiency, defined as the ability to harvest enough rice to sustain a family for 12 months or more, declined significantly over a 10year study period that encompassed the onset or intensification of industrial logging activities ( $\mathrm{O}^{\prime}$ Connor \& Curran, in preparation).

Concessions also contribute to wildlife population declines, through habitat loss and increased hunting (Robinson \& Bennett, 2000). Dayak hunters perceive a decrease in prey species since logging activities commenced, despite a significant decrease in the proportion of local residents who hunt for subsistence. The total number of hunters in the area, however, more than doubled over the decade, because concession employees hunt throughout the logged and unlogged areas $\left(\mathrm{O}^{\prime}\right.$ Connor \& Curran, in preparation).

Increased reliance on concessions and wage labor. The logging and plantation companies employ hundreds of Javanese as skilled laborers; these migrant workers live on the concession compounds in barracks, often with their families. Concomitant with the influx of outsiders, Dayak villages have been undergoing a transition into a market economy. Concession employees and their families create a large demand for a wide range of goods, and they must buy almost all their food from concession stores or local communities. The concession facilitates this market system by sending a truck to each village once a week to transport villagers and their 
wares—vegetables, eggs, freshly hunted meat and other forest products-to the logging camps.

Local Dayak residents often work for the company, although generally in unskilled positions for relatively low pay. However, the company has brought unprecedented opportunities for steady cash income, allowing some local residents to earn their livelihoods outside the agricultural sector. There is also increasing potential for socio-economic inequality within villages, as some families earn more wages than others.

Timber concessions are required to invest in development of villages located within and near the concession borders. In Kalimantan, where the vast majority of the land is designated as production forest and managed by private companies, the private sector has taken on the traditional governmental role of providing community development and extension services. Concessions provide electricity, roads, health clinics, schools and teachers. In turn, these communities feel indebted to non-local, private companies, whose primary interest is maximizing resource extraction and for whom there is little political, economic, or legal accountability.

Companies pay village leaders and other powerful local residents to ensure their cooperation (Dove \& Kammen, 2001). These "wages" are not fixed: the company pays more to leaders from whom the company most wants compliance, such as those in villages near logging activities. These pay-offs alter the balance of power in villages, because the companies usually pay the government-approved representative (kepala desa) rather than the locally chosen leader (kepala adat). The provincial government carefully selects the pool of kepala desas (Alcorn, Bamba, Masiun, Natalia, \& Royo, 2003), and those who are chosen are often not respected in the village. Historically, Dayak societies have not been defined by classes or rank. However, as measures of resources change from subsistence value, such as amount of rice or hunted meat, to cash income and its attendant purchasing power, new dynamics are emerging in these villages. Outside income may become a new "culturally defined value" (Cronk, 1991).

Ethnic conflicts. Market interactions with the concession are creating unequal access to power and distribution of resources, both within and among Dayak villages and among local communities, migrants, and corporate interests. In addition to the migrant logging concession workers, industrial plantations often employ large numbers of transmigrant workers. Increasing numbers of outsiders lead to degraded landscapes, because outsiders' interests are short-term, and their knowledge of local ecology is limited. Rising population pressure has resulted in decreases in faunal resources and in available land. Local residents, who do not reap benefits from industrial resource exploitation and are often powerless to resist or 
enforce their rights, are increasingly frustrated and angry. Conflicts between local communities and logging concessions over land, jobs, and other resources have become common. For example, in West Kalimantan several logging camps were burned by local residents, and there has been physical violence between locals and loggers.

\section{CONCLUSION AND IMPLICATIONS}

Despite the fact that many countries, including the United States, acknowledge that there are conditions under which central management of natural resources can be most effective, Indonesia's version of centralized control has not been successful at protecting forests or reducing resource demands. Lack of control by local resource-users routinely leads to overexploitation (Ostrom, 1990), as has occurred on the outer islands. Transmigration and industrial forest conversion, and the interactions between the two programs, have led to undesirable local outcomes, including increased population pressure on the forest resources of the outer islands, depleted natural resources, and ethnic conflict. Both programs engender statedependent communities, and migrants and residents alike will be left with few resources once state subsidies expire.

Transmigration to less-populated areas is not a panacea for either Indonesia's population crisis or for the individual families that choose to move. Transmigration settlements often become nearly as densely populated as the inner islands, feeding criticism that the program is just a method of moving rural poverty away from Java. Transmigration fails to provide the security people seek: there is still no reliable system of ownership or possession, and the settlers face difficult conditions: poor soils, ethnic conflicts with the local population, and limited access to social services and health services (Economist, 1994).

The Indonesian government, and foreign development agencies such as the World Bank, still support the transmigration program-despite its limited success, international criticism, and problems of ethnic conflict and ecological degradation (Fearnside, 1997; McBeth, 1994). A 1996 government propaganda pamphlet confirms that the government's goals for transmigration into the next century are similar to the historical goals of reducing population pressure and distributing population more evenly (Zakaria, 1996).

Industrial forest conversion has affected the livelihoods of local subsistence communities, who have been forced to enter a market economy as local forest resources disappear. Forest-dependent communities have 
become company-dependent communities. Industrial logging concessions are abandoning sites as their leases expire or as their lands lose productivity. Local residents who recently converted to a cash economy will have to adapt again in response to the loss of markets, transportation, and forest resources. A potential cycle of dependency has been created, and communities may face resource shortages once the concessions depart.

Recognizing the limitations of central control, Indonesia recently began to shift power to local units of government. However, decentralization - the major reorganization of Indonesia's government to devolve power and control to the district level—has exacerbated the confusion over control of forest resources. There are at least 15 different statutes and regulations that apply to the control and management of forested land in Indonesia (Gunawan et al., 1999). This morass of legislation is difficult to understand and to enforce, especially for rural communities with little access to education or formal legal information. Decentralization to district and municipal governments may bring more problems than solutions (Thorburn, 2002). Indeed, illegal logging has flourished under the new regional autonomy laws (Casson \& Obidzinski, 2002; Curran et al. 2004), and decentralization has led to increased ethnic and economic tensions (Hugo, 2002).

Solutions to environmental and ethnic conflicts will require an understanding of the behavioral ecology as well as the political ecology of resource use, and a balance of local and central control. Influences on local livelihoods of large-scale land use, population movements, and economic shifts are as important as the changes in behavior within local communities (Steinberg, 1998). Although complete decentralization of resource management may not be appropriate for Indonesia, some local control or feedback must be built into any effective management regime. This review has highlighted the impacts of transmigration and forest conversion on land use and forest-dependent communities. Empirical data are needed to elucidate the extent of the interactions between these programs, and to assess how the apparent synergies affect access to land, jobs, and forest resources for local residents and migrants alike.

\section{REFERENCES}

Abdoellah, O. S. (1987). Transmigration policies in Indonesia: Government aims and popular response. In S. Morgen \& E. Colson (Eds.), People in Upheaval (pp. 180-196). New York, NY: Center for Migration Studies.

Abernathy, V. D., \& Penaloza, R. V. (2002). Fertility-decline in former "Asian tigers." Population and Environment 23, 245-265. 
Alcorn, J. B., Bamba, J., Masiun, S., Natalia, I., \& Royo, A.G. (2003). Keeping ecological resilience afloat in cross-scale turbulence: An indigenous social movement navigates change in Indonesia. In F. Birkes, J. Colding, \& C. Folke (Eds.), Navigating SocialEcological Systems: Building Resilience for Complexity and Change (pp. 299-327). Cambridge: Cambridge University Press.

Barber, C.V. (1998). Food resource scarcity \& social conflict in Indonesia. Environment 40, $4-20$.

Broad, R., \& Cavanagh, J. (1994). Borneo on the brink: Of rainforests and robber barons. The Amicus Journal 16, 18-21.

BPS (Badan Pusat Statistik). Accessed 12 March 2004. website: http://www.bps.go.id/sector/ population/ table3.shtml.

Cairns, M., \& Garrity, D. P. (1999). Improving shifting cultivation in Southeast Asia by building on indigenous fallow management strategies. Agroforestry Systems 47, 37-48.

Casson, A., \& Obidzinski, K. (2002). From new order to regional autonomy: Shifting dynamics of "illegal" logging in Kalimantan, Indonesia. World Development 30(12), 2133-2151.

CIA (2003). The World Factbook. United States Central Intelligence Agency. Accessed March 6 2004. website: http://www.cia.gov/cia/publications/factbook/geos/id.html.

CIFOR, Centre for International Forestry Research (2002). Illegal logging in Indonesia. Accessed November 23 2002. website: http://www.cifor.cgiar.org/publications/newsonline/ 30/illegal-logging.htm.

Clarke, A. L., \& Low, B. S. (2001). Testing evolutionary hypotheses with demographic data. Population and Development Review 27(4), 663-660.

Clauss, W., Evers, H.-D., \& Gerke, S. (1987). The formation of a peasant society: Population dynamics, ethnic relations, and trade among Javanese transmigrants in east Kalimantan, Indonesia. Wirkungen der Transmigration, No. 2. Hamburg: Universitat Bielefeld.

Cohen, J. E. (1995). How Many People Can the Earth Support? New York, NY: W.W. Norton \& Company.

Cronk, L. (1991). Human behavioral ecology. Annual Review of Anthropology 20, 25-53.

Curran, L. M., Caniago, I., Paoli, G. D., Astinani, D., Kusneti, M., Leighton, M., Nirarita, C. E., \& Haeruman, H. (1999). Impact of El Niño and logging on canopy tree recruitment in Borneo. Science 286, 2184-2188.

Curran, L. M., Trigg, S. N., McDonald, A. K., Astiani, D., Hardiono, Y. M., Siregar, P., Caniago, I., \& Kasischke, E. (2004). Lowland areas of forest loss in protected areas of Indonesian Borneo. Science 303, 1000-1003.

Dawson, G. (1994). Development planning for women: the case of the Indonesian transmigration program. Women's Studies International Forum 17, 69-81.

de Jong, W. (1997). Developing swidden agriculture and the threat of biodiversity loss. Agriculture, Ecosystems and Environment 62, 187-197.

Desbarats, J. (1990). Population resettlement programs in comparative perspective: A review (pp. 1-29). Canberra: Australian National University.

Dove, M. R. (1986). Peasant versus government perception and use of the environment: A casestudy of Banjarese ecology and river basin development in South Kalimantan. Journal of Southeast Asian Studies 17, 113-136.

Dove, M. R., \& Kammen, D. M. (2001). Vernacular models of development: An analysis of Indonesia under the "New Order." World Development 29, 619-639.

Economist (1994). Indonesia: Hungry for land. The Economist 4 March, (1994), 39.

Elmhirst, R. (1999). Space, identity politics and resource control in Indonesia's transmigration programme. Political Geography 18(7), 813-835.

Elmhirst, R. (2000). A Javanese diaspora? Gender and identity politics in Indonesia's transmigration resettlement program. Women's Studies International Forum 23(4), 487-500.

Fasbender, K., \& Erbe, S. (1990). Towards a New Home: Indonesia's Managed Mass Migration. Hamburg: Verlag Weltarchiv GMBH.

Fearnside, P. M. (1997) Transmigration in Indonesia: Lessons from its environmental and social impacts. Environmental Management 21(4), 553-570. 
Fox, J. M. (2000). How blaming "slash and burn" farmers is deforesting mainland Southeast Asia, pp. 1. 8. Honolulu, HI: East-West Center.

Geronimus, A. T. (1996). What teen mothers know. Human Nature 7, 323-352.

Gunawan, R., Thamrin, J., \& Suhendar, E. (1999). After the Rain Falls ... The Impact of the East Kalimantan Forestry Industry on Tribal Society. Bandung, Indonesia: AKATIGA Foundation.

Holden, S., Hvoslef, H., \& Simanjuntak, R. (1995). Transmigration settlements in Seberida, Sumatra - Deterioration of farming systems in a rain-forest environment. Agricultural Systems 49(3), 237-258.

Hugo, G. (1980). Indonesia: Population distribution and redistribution. Majalah Demografi Indonesia 7, 70-100.

Hugo, G. (2002). Pengungsi — Indonesia's internally displaced persons. Asian and Pacific Migration Journal 11(3), 297-331.

Hull, T. H. (1976). The influence of social class on the need and effective demand for children in a Javanese village. In L.T. Ruzicka (Ed.), The Economic and Social Supports for High Fertility (pp. 287-306). Canberra: Australian National University.

Hull, T. H. \& Dasvarma, G.L. (1987). The 1985 intercensal survey of Indonesia: Evidence of continuing fertility decline. Canberra: Australian National University.

Hull, T. H. \& Hatmadji, S. H. (1990). Regional fertility differentials in Indonesia: Causes and trends. Canberra: Australian National University.

Ilchman, W. F., Lasswell, H. D., Montgomery, J. D., \& Weiner, M. (Eds.) (1975). Policy Sciences and Population. Lexington, MA: Lexington Books:

Jones, G. W. (1976). Economic and social supports for high fertility: conceptual framework. In L. T. Ruzicka (Ed.), The economic and social supports for high fertility (pp. 3-39). Canberra: Australian National University.

Karyono, L. C., Abdoellah, O., \& Siswandono (1980). Potential of homegarden in tidal transmigration areas, south and central Kalimantan. In Seminar of the Ecology of Homegarden III, Bandung, Indonesia: Institute of Ecology, Padjadara University.

Low, B. S. (1993). Ecological demography: A synthetic focus in evolutionary anthropology. Evolutionary Anthropology 1, 177-187.

Low, B. S. (2001). Sex, wealth, and fertility: Old rules, new environments. In L. Cronk, N. Chagnon, and W. Irons (Eds.), Adaptation and Human Behavior: An Anthropological Perspective, New York: Aldine.

Low, B. S., Clarke, A. L., \& Lockridge, K. A. (1992). Toward an ecological demography. Population and Development Review 18, 1-31

Lumbranraja, J., Syam, T., Nishide, H., Mahi, A.K., Utomo, M., Sarno, \& Kimura, M. (1998). Deterioration of soil fertility by land use changes in south Sumatra, Indonesia: From 1970-1990. Hydrological Processes 12, 2003-2013.

MacAndrews, C. (1986). Land Policy in Modern Indonesia: A study of land issues in the New Order period. Boston, MA: Oelgeschlager, Gunn \& Hain.

MacKinnon, K., Hatta, G., Halim, H., \& Mangalik, A. (1997). The Ecology of Kalimantan. The Ecology of Indonesia Series. Oxford University Press.

McBeth, J. (1994). At Loggerheads: Irianese feel threatened by influx of migrants. Far Eastern Economic Review 10 March (1994), 50-52.

O'Connor, C. M., \& Curran, L. M. (in preparation). Subsistence hunting, swidden agriculture, and commercial logging: Implications for local community livelihoods and equitable resource management.

Oey, M. (1981). The impact of migration on fertility: a case study of transmigrants in Lampung, Indonesia. Ph.D. dissertation, University of Australia.

Ostrom, E. (1990). Governing the Commons: The Evolution of Institutions for Collective Action. Cambridge: Cambridge University Press.

Rank, M. R. (1989). Fertility among women on welfare: Incidence and determinants. American Sociological Review 54, 296-304.

Robey, B., Rutstein, S. O., \& Morris, L. (1993). The fertility decline in developing countries. Scientific American, 60-67. 
Robinson, J. G. \& Bennett, E. L. (2000). Hunting of wildlife in tropical forests: Implications for biodiversity and forest peoples. Washington, D.C.: The World Bank.

Shankar, R., \& Shah, A. (2003) Bridging the economic divide within countries: A scorecard on the performance of regional policies in reducing income disparities. World Development 31(8), 1421-1441.

Steinberg, M. K. (1998). Political ecology and cultural change: Impacts on swidden-fallow agroforestry practices among the Mopan Maya in southern Belize. Professional Geographer 50, 407-417.

Suharto, S., \& Cho, L-J. (1978). Preliminary estimates of Indonesian fertility based on the 1976 intercensal population survey. Papers of the East-West Population Institute, No. 52. Honolulu, HI: East-West Center.

Thorburn, C. (2002). Regime change—Prospects for community-based resource management in post-new order Indonesia. Society and Natural Resources 15(7), 617-628.

Wadley, R. L., Pierce Colfer, C. J., \& Hood, I. G. (1997). Hunting primates and managing forests: The case of Iban forest farmers in Indonesian Borneo. Human Ecology 25, 243-271.

Williams, L. (1986). The relationships among migration, women's decision making power, and fertililty in rural central Java. In Annual Meeting of The Population Association of America, San Francisco, CA.

Zakaria, K. (1996). Transmigration to Build a Better Future. Directorate of Foreign Information Services, Jakarta. 